north it scarcely amounts to 3 cubic feet. Nor is the return very satisfactory from a pecuniary point of view, most of the Governments being far under one rouble per dessiatine, though a few can show better results, those of Moscow, Kursk, and Voronetz being $3 \frac{1}{2}$ roubles, of Charkow $5 \frac{1}{2}$, Tula $6 \cdot \mathrm{r} 6$. But the general value is not as satisfactory as in other countries, Prussia showing an equivalent of $2 \frac{1}{2}$ roubles, Bavaria $4 \frac{1}{2}$, Saxony 10, and France 9. One of the most useful developments of tree cultivation in 'Russia has been the formation of plantations along the railway tracks, about 2000 dessiatines having been already covered in this way on the Kursk-CharkoffAzov, the Kozloff-Voronetz-Rostoff, the Orel-Griasi and Fastovo lines, the object being of course the protecting of the rails from snowdrift. M. Sredinsky, the inventor of this very successful system, considers that seven rows of trees are sufficient for this purpose, and on this calculation one verst would require 33,000 plants, of which 9000 must be trees, and the remaining 24,000 shrubs. The trees which he finds best adapted for this purpose are elm, ash, oak, white and yellow acacia, maple, white thorn, hazel (Coryhus avellana), wild plum, gleditschia, mulberry, elder, \&c., but along the Sumi Railway in the Government of Charkoff, Pinus sylvestris has been planted, and does well. Treeplanting has also proved invaluable for fixing the sand plains at Aleschki on the Dnieper, the best for this purpose being Salix acutifolia, Genista tinctoria, Ulex europaus, Prunus spinosa, and Pinus maritima. When Russia first got possession of the Crimea, the banks of the Dnieper were wooded for at least seventy versts ; but, as colonisation extended and population increased, the herds and flocks destroyed the rosts of the trees, and thus allowed the formation of these sand plains, which comprise 139,000 dessiatines. Of these, some 20,000 are fairly covered with Salix viminalis. Birch are found on about I0,000 dessiatines, while at least 34,000 are of the pure sand.

\section{THE AMERICAN INITIATIVE IN METHODS OF DEEP-SEA DREDGING ${ }^{1}$}

THE published records respecting the use of dredges for natural history purposes carry us back to scarcely more than a century and a quarter ago, when Otho Frederick Müller, a prominent Danish naturalist, began his studies of the aquatic life inhabiting the coasts of Norway and Denmark below the shore-level. The dredge he used, a very simple affair, was, so far as we know, the first one ever devised for the special needs of the naturalist ; and yet, with only a single important modification as to the shape of the frame, it has been handed down to our time as the most efficient appliance for the ordinary purposes of dredging.

As described and figured in $\mathbf{I 7 7 9}$, it consisted of a plain rectangular iron frame, with all four sides of equal length, and bevelled to sharp edges in front, forming the mouthpiece to a large and open net. Four handles extended forward from the angles, and met in a single ring for the attachment of the dragrope. The principle defect of this dredge consisted in its very wide mouth, permitting the easy escape of specimens both while dragging and during the hauling in.

Although Müller's researches were confined to shallow water, apparently not exceeding a depth of thirty fathoms, they established a precedent for subsequent operations, and afforded proof of the value of submarine collecting.

This new field of exploration did not, however, begin to enlist the active services of working naturalists to any cxtent until about the third or fourth decade of the present century, since which time the interest in marine zoological research has rapidly increased, and our knowledge of the sea-bottom has been extended to the deepest-known areas. For the first thirty or forty years the improvement in methods of work scarcely kept pace with the progress of knowledge regarding the inhabitants of the sea; and it is only within the past fifteen years that the methods of deep-sea dredging have been at all perfected.

To Dr. Robert Ball of Dublin, who was afterwards associated with Prof. Edward Forbes in his memorable explorations, has generally becn given the credit of having devised, about 1838 , the improved form of naturalists' dredge, in nearly the same shape in which it is used to-day. Iowever that may be, it was about the year last mentioned that both European and American naturalists entered actively into the study of the sea-bottom and the history of their various exploits down to the present

$$
\text { I From Sicience. }
$$

time affords an exceedingly interesting chapter, upon which the subject of our paper permits us to touch but slightly.

It may be well to remark, however, that the character and results of European, and especially British, exploration are much more widely and popularly known than are those of our own country. The reason is obvious. The active mercantile pursuits of a young and progressive people have naturally made them less appreciative of scientific facts and results than the inhabitants of many older countries, where business interests have fewer claims upon all classes. There has been but a slight demand for popular writings upon such an unpractical subject, and the plodding naturalist has generally been content to record his observations and methods where they were accessible only to his brother-workers. For this reason American naturalists have not received the credit which is their due, either at home or abroad; and much of the honour that justly belongs to them has passed into other hands.

So far as concerns the general public, this is not to be wondered at, when we consider that the only popular accounts of deep-sea dredging explorations obtainable in this country are of English origin. But the same excuse does not hold good for the working naturalists of any country, including our own; as the progress of American deep-sea research, and the improvements in methods for carrying it on, have in nearly all instances been duly and promptly recorded in the proper channels to insure wide and timely distribution.

Since the very beginning of activity in this branch of investigation, American workers have not been far behind those of any European country ; and their record is as creditable. Dredging was carried on by the Wilkes U.S. Exploring Expedition during the early part of its cruise, beginning in 1838 ; and at about this same time a few of our most earnest naturalists were using the dredge at home. The late Dr. William Stimpson, one of the most intelligent observers in this branch, and whose name is closely linked with several important explorations, began his career in Boston Harbour between 1848 and 1850 ; his first instructions having been received from Dr. W. O. Ayres, who began dredging fully ten years before. Stimpson's researches were largely conducted under Government auspices; and the collection of submarine specimens resulting from his labours, distributed over many portions of the Atlantic and Pacific Oceans, was probably one of the very largest of its kind that had been made, up to the time of its unfortunate destruction by fire at Chicago, in $187 \mathrm{r}$. The loss of these collections, and of all the voluminous manuscript reports treating of them, followed by the sad death of the author, has deprived our country of a most important chapter in the history of submarine exploration.

The sixth decade of this century, however, brought out many additional investigators, and a fresh impetus was given to the work, which has since been expanded and developed to such an extent as to establish beyond all question American precedence in the methods of deep-sea research at least, both as regards dredging and sounding.

From among the more energetic and successful of our modern dredgers may be mentioned Prof. A. E. Verrill of Yale College, whose dredging studies began in 1864, on the coast of Maine, and who, since the organisation of the U.S. Fish Commission, has been its main helper and adviser in all matters pertaining to submarine research, the special direction of the dredging operations having been intrusted to him from the beginning. His earlier experiences gave him a clear insight into the requirements of the ncw project, and enabled him to devise many valuable appliances, and improve upon those which had been in use. To his zealous and untiring efforts is due much of the perfection in present methods of work.

In 1867 Mr. L. F. de Pourtalès, of the U.S. Coast Survey, began the extensive series of deep-sea explorations off the southern coast of the United States, which were carried on for several years, and subsequently led to the eventful cruises of the steamer Blake between $\mathbf{1} 877$ and $\mathbf{1} 880$, resulting in an entire revolution in the methods of deep-sea dredging and sounding. The investigations of Mr. Pourtales anticipated by a year those of the English steamers Lightning and Porcupine, which have been so widely described, and were preceded by only one series of systematic dredgings in equal depths of water-those of the Professors Sars, father and son, of Norway. But little credit for this fact has been received from naturalists abroad, the date of Mr. Pourtalès' first cruise being generally regarded by them as I868, although his first paper, descriptive of the character of his work and of many new forms of deep-sea animals, appeared in 
December $1867 .^{1}$ His collections, representing principally the fauna of the Gulf Stream off Florida, gave new and interesting results, going farther to prove the existence of a rich and diversified deep-sea fauna, different from that of the shore regions, than any previously obtained.

That these dredgings were not undertaken to please the passing whim of some over-enthusiastic naturalist, but were as deliberately planned and carried out, and as successful in their results, as those of the English steamers which followed them in conception, a reference to the official publications of the Coast Survey will sufficiently prove. As substantiating this statement, we may be pardoned for quoting a short paragraph from the report of Mr. Pourtalès, above referred to (December I867), in which the plans and objects of the new explorations are briefly stated. This would not be called for, were it not that it is this identical report which has been so utterly ignored by European writers, and equally overlooked by many Americans. Had it only been written in popular language, and been published with copious illustrations, it might have received the credit which has been denied it; hut such channels of publication are seldom deemed necessary to establish priority in scientific research.

The plan of operations, according to Mr. Pourtales, was as follows :-

"The present Superintendent of the Coast Survey, Prof. B. Peirce, has lately directed the resumption of the investigations of the Gulf Stream, so successfully inaugurated by his predecessor, but interrupted for several years by the war. Besides observations of the depth, velocity, and direction of that current, and the temperature and density of the water at different depths, the researches will be extended to the fauna of the bottom, of the surface, and of the intervening depths. Not only will an insight be thus obtained into a world scarcely known heretofore, but that knowledge will have a direct bearing on many of the phenomena of that great current. Thus a new light may be thrown on its powers of transportation from shallow to deeper water or along its bed, on its action of forming deposits in particular localities, or on its possible influence on the growth of coral-reefs on its shores."

In a subsequent passage he summarises his first season's results in the following terse remarks, the italics being his own :--

"However, short as the season's work was, and few as were the casts of the dredge, the highly interesting fact was disclosed, that animal life exis's at great depths, in as great a diversity and as great an abundance as in shallow zwater."

Early in the following year (I868) the same explorations were resumed, and they were continued through 1869 .

It may be thought that we have departed too widely from our subject in discussing with so much detail the progress of American research during a period in which no great improvements were made in methods of work on this side of the Atlantic; but how could we have better furnished pronf of the rapid growth of interest in such matters, and of the maturing of ideas which prepared the way for the important changes marking the next decade.

'There is, however, one noteworthy addition to the collector's outfit made in this period, which deserves special mention. On one of the dredging cruises of the English exploring steamer Purcupine, between 1868 and 1870 , Capt. Calver, the naval officer in charge, attached several of the common deck-swabs to the end of the dredge-net, with the expectation that, in sweeping the ocean-bottom, they would securely entangle all the rough and spiny objects lying loose within their path. IIis fondest hopes were realised, and the novel experiment, suggested by often finding such objects as sea-turchins, corals, and sponges, adhering to the exterior of the dredge-net, and even to the lower part of the dra $y$-rope, gave origin to one of the most efficient implements of modern deep-sea research.

When the beam-trawl, a well-known English appliance for the capture of bottom-fish, was first adopted into the outfit of the marine zoologist, we are unable to state; but it does not appear to have ever been extensively and systematically employed in scientific research until so used by the U.S. Fish Commission, beginning in 1872 . It was afterwards used by the Challenger from 1873 to 1878 , and now greatly excels the dredge in the extent and value of its results, wherever the ground is suited to its use.

The year I871 was signalised by the organisation of the U.S. Fish Commission, one of the most important scientific establishments of modern times for marine zoological work. Although

'Bulletin Mus. Comp. Zool., Cambridge, vol. i., r863-69, pp. ro3-120. instituted primarily for the investigation of fishery matters, it has, through the wise and liberal policy of its Director, Prof. Baird, accomplished most valuable results for marine biology. The latter department has been sedulously fostered, in the belief that its results would have an important bearing upon the practical questions at issue. No pains bave been spared to perfect the methods of research, and many valuable contributions have already been made to the marine collector's outfit. These are briefly described below, and, as the history of the Commission is already well known to most readers, we need refer here to only a few points which have marked its progress.

The earlier explorations were carried on mainly by means of sail-boats, and were confined to comparatively shallow water. From 1873 to 1879 a naval tug was placed at the disposal of the Commission every year; but in 1880 the steamer Fish Hawk, a twin-screw propeller of 205 tons (n.m), was built expressly for the combined purposes of fish-hatching and dredging. Its small size and light draught prevented long trips at sea, but it was well adapted for deep-sea work, and was supplied with all the improved appliances, as well as those which had originated with the Commission, including wire rope, then recently introduced by the Coast Survey. In I883 the steamer Albatross, described in vol. ii. of Science (pp. 6, 66), was completed, and made her first successful cruise in the spring of that year. Her log for the summer of $\mathrm{I} 883$ records the deepest trawling yet made in the Atlantic Ocean, the depth having been 2949 fathoms, and the results successful. Brief accounts of her dredging cruises under Lieut.-Commander Tanner, U.S.N., have appeared from time to time in late numbers of Science.

While the Fish Commission claims priority for many improve. ments in apparatus primarily intended for depths under a thousand fathoms, it willingly yields the palm for deep-sea improvements to the U.S. Coast Survey, especially in the persons of Commander Sigsbee, U.S.N., and Mr. Agassiz. The explorations of the steamer Blake from 1877 to 1880 , in which the methods of deep-sea dredging and sounding were completely revolutionised, mark one of the most important stages in the progress of marine research. Wire rope was substituted for hemp, the dredge was altered to adapt it to the soft bottoms of deep water, on which dredging results had always been uncertain, and the beam-trawl was made reversible. The methods of handling and reeling the rope were also perfected. These changes and additions were briefly described and figured from time to time as work progressed in the Bulletin of the Museum of Comparative Zoology, at Cambridge, by Mr. Agassiz and Mr. Sigsbee, and were afterwards fully discussed by the latter in one of the most elaborate and instructive reports ever dedicated to the methods of deep-sea research. ${ }^{1}$ It is a quarto volume of 208 pages and 4I plates, describing the sounding and dredging appliances used by the Blake, and which, for the greater part, were devised or improved during her dredging cruise. So far as her dredging appliances are concerned, the credit for changes made belongs mostly to $\mathrm{Mr}$. Sigsbee and $\mathrm{Mr}$. Agassiz, the former having been in command of the expedition, and the latter in charge of the natural history operations.

During the seventh decade, European explorers were not idle, and numerous deep-sea expelitions were fitted out. Mosi notable among these was the cruise of the British ship Challenger around the world between 1873 and 1878 . Her scientific results were most interesting; but the older methods of deep-sea work were not greatly altered, although the practicability of using the beam-trawl successfully in the deepest water was fully demonstrated.

In $188 \mathrm{I}$ the French Government inaugurated a series of submarine explorations in the Atlantic Ocean and Mediterranean Sea; for that purpose fitting out a small naval vessel, the Trazailleur, and placing the management of affairs in the hands of a competent scientific staff, under the directorship of Prof. A. Milne-Edwards. These investigations were continued by the same vessel during 1882 , the appliances and methods of work having apparently been patterned after those gencrally recognised in Europe. In I883 a larger vessel, the Talisman, was assigned to the work, and operations were established on a much grander scale than before.

For an account of these explorations, descriptive of the methods of work and general results, we are indebted to the last volume of $L a$ Nature, a French journal of the character of

"Deep-Sea Sounding and Dredging: a Description and Discussion of the Methods and Appliances used on Board the Coast and Geodetic Survey Assistant on the Coast and Geodetic Survey. (Washington, x880.) 
Science, which began in a January number the publication of a series of articles by one of the naturalists who accompanied the steamer. ${ }^{1}$ Coming from such an authoritative source, we are led to regard these papers almost in the light of a semi-official report, and look to them for at least a correct statement regarding the origin of their methods of work, inasmuch as these matters are discussed in some detail, and with evident pride at the completeness of the outfit. That the outfit was complete no one who is at all posted on the subject can deny; for nearly all of the many improvements introduced by the Coast Survey and Fish Commission prior to 1880 are most faithfully copied, and most heartily praised for their perfect adaptation to the requirements of research.

We glance through the several pages of the report for at least some slight acknowledgment on behalf of American inventive skill ; but beyond a brief statement to the effect that the hoistingengine "was of the same type as that employed by Mr. Agassiz," and that he also " used with good results the common form of beam-trawl," we are left to infer that the entire outfit was of French origin; and such must be the impression of every one who reads these papers. In fact, in several instances, credit is explicitly bestowed on French inventors for certain of the appliances which do not differ in any essential features from the corresponding American patterns.

What is to be gained by thus appropriating to the credit of a nation what properly belongs to another and a friendly one, by all the rights of international courtesy, it is difficult to understand, and especially so in this age of supposed enlightenment, when every important discovery is carried with lightning rapidity to all parts of the civilised world. The field of marine research is sufficiently broad to engage the entire attention of all the naturalists who have yet entered it ; and the frequent manifestations of jealousy on the part of foreign, and especially French, investigators, which often result in wholly ignoring the works of an able American author, can but retard progress instead of aiding it.

Proofs of the superior excellence of American methods of deep-sea research may be found in every important scientific library of Europe as well as this country ; and at the two most prominent International Fisheries Exhibitions of the worldthose of Berlin in 1880 , and London in 1883 - all of the American appliances were displayed, and received the highest awards. They have therefore been made sufficiently well known to establish their merits before the scientific world; but, as no descriptions of them have yet been published for the benefit of the general public, we propose in future numbers of Science to give accounts of their construction, and of the causes which lead to their introduction.

RICHARD RATHBUN

\section{WHY TROPICAL MAN IS BLACK}

THERE are few subjects the explanation of which has taxed the ingenuity of man more than the existence of extremes of colour in different sections of the human race. Tradition has attributed the dark race to one of three brothers, the other two being progenitors of the opposite hue, without at the same time offering any solution of the variation from a common stock.

Physiologists have vaguely asserted that a black skin is best suited to a hot climate, but do not attempt to reconcile the fact that a black coat is certainly the least adapted to the same condition. Evolutionists would doubtless say that in those early days when man in the dense forests of the time was fighting his brave struggle of brain against fangs and claws, the dark skin mingling with the shadows of the overhanging foliage gave him a chance of survival ; but this reaches the conclusion that the first men were black, and that all white men proceeded out from these.

Yet even if this be so, and if the dark skin served only for concealment, why on the burning tablelands and treeless undulations of Central and Southern Africa, where there is scarce a bough to shelter him, has man for so many thousand years preserved a colour which has become the standard of all blackness? Surely there must be some other explanation of the fact that man beneath the vertical rays of a tropic sun has persisted in maintaining a hue of skin which would appear to have the effect only of absorbing and accumulating the intense heat of his surroundings. Some reason why the ryot of India can labour in the plains

I For an abstract of the portion relating to the apparatus employed, see Science, No. 62. clad only in the scantiest loin-cloth, and why the African can limit his full dress to a few inches of monkey-tails.

The rapidly accumulating evidence of the practical utility of every peculiarity, and the proofs that nature, by hoarding up a little of each individual advantage through countless generations, has arrived at the best condition for each environment, compe us to realise the fact that in the tropics darkness of skin contributes to survival.

That this colour will absorb heat more than any other is as true of the skin of a man as of the roof of a house; therefore the anomaly is reached that in the tropics he is fittest who is hottest, so long as heat is regarded as the only factor in the consideration. But that one cannot live by heat alone is as true of the animal kingdom as of the whole vegetable world. Light, the twin stimulant of life, because perceptible to out consciousness by its action on a specialised nerve, has been too much limited in our conceptions of its influence to that duty only.

The gigantic processes of nature by which the great vegetable world, past and present, has been built up, the oxygen of water divorced from its hydrogen in the leaves of plants, and carbonic acid resolved into its constituents, were and are accomplished by the light-waves of the sun; and yet in the animal kingdom the action of these waves upon the eye is held to be almost their sole effect.

The craning offshoot of a window-plant, the twisted leaves of an indoor flower are sufficient evidence of the resistless power of light, and the proofs of its effect on man are as numerous as those of its action on plants; the mode only of that action is the mystery, and yet if this can be even partially explained, enough may be attained to show why those in whom a portion of the rays of the glaring tropic sun are blocked at the surface are best adapted for survival beneath its vertical beams.

As has been expressed by Prof. Tyndall ("Atoms, Molecules, and Ether Waves," Longman's Magazine, Nov. I882) "We know that all organic matter is composed of ultimate molecules made up of atoms, and that these constituent atoms can vibrate to and fro millions and millions of times in a second." Nerve is organic matter, and "whether we meet with nerve tissue in a jelly fish, an oyster, an insect, a bird or a man, we have no difficulty in recognising its structural units as everywhere more or less similar. These structural units are microscopic cells and microscopic fibres, the function of the fibres is that of conducting impressions (represented by molecular movements) to and from the nerve cells, while the function of the cells is that of originating those of the impressions which are conducted by the fibres outwards," (vide "Mental Evolution in Animals," Romanes).

We can conceive then that the way in which a nerve-fibre conveys to a more central nerve-cell an impression from the surface is by rapid vibration of its component molecules. Such vibrations can be rudely originated by contact, pressure, or such like stimuli, till they give rise to feeling, or, if severe, to pain, but they can be not only improvised, they can be communicated. The simplest illustration of vibrations being communicated is when a piano is opened and sung into; whereupon the string whose tension coincides with the uttered note will take it up and pass it on in sound. If then vibrations were taking place in the immediate vicinity of the sentient extremities of nerves all over the surface of the body, the same would be expected to occur.

The waves of light and heat follow each other at similar rates through the luminiferous ether.

Man lives at the bottom of a measureless ocean of this subtle medium, and is, in common with all else in the universe, permeated by it. "When, therefore, light or radiant heat impinge, like the waves of sound just adverted to, their waves select those atoms whose periods of vibration synchronise with their own periods of recurrence, and to such atoms deliver up their motion. It is thus that light and radiant heat are absorbed." (Tyndall).

Is it not from this easily intelligible how heat-waves notify their existence and intensity along the surface fibre to the central nerve cell, and so enable the animal to avoid their action, if excessive, or seek their increase, when deficient. And shall it be said that while the heat-waves are thus received, and responded to, through every instant of existence, their fellowworkers, the waves of light, are practically inert except for the stimulation of the one specialised nerve of the eye?

By going from the complicated and compound to the structureless and simple, the question can be answered in no uncertain 